\title{
Article
}

\section{Respect for Just Revenge}

\author{
Rosebury, Brian
}

Available at http://clok.uclan.ac.uk/3396/

Rosebury, Brian ORCID: 0000-0002-6154-2685 (2008) Respect for Just

Revenge. Philosophy and Phenomenological Research, 77 (2). pp. 451-471. ISSN 0031-8205

It is advisable to refer to the publisher's version if you intend to cite from the work. http://dx.doi.org/10.1111/j.1933-1592.2008.00198.x

For more information about UCLan's research in this area go to http://www.uclan.ac.uk/researchgroups/ and search for < name of research Group>.

For information about Research generally at UCLan please go to http://www.uclan.ac.uk/research/

All outputs in CLoK are protected by Intellectual Property Rights law, including Copyright law. Copyright, IPR and Moral Rights for the works on this site are retained by the individual authors and/or other copyright owners. Terms and conditions for use of this material are defined in the policies page.

\section{CLoK}

Central Lancashire online Knowledge www.clok.uclan.ac.uk

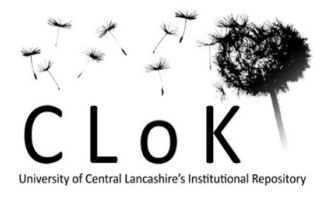




\title{
RESPECT FOR JUST REVENGE
}

\begin{abstract}
The paper considers acts of private (in the sense of individually motivated and extralegal) revenge, and draws attention to a special kind of judgement we may make of such acts. While endorsing the general view that an act of private revenge must be morally wrong, it maintains that under certain special conditions (which include its being just) it is susceptible of a rational respect from others which is based on its standing outside morality, as a choice by the revenger not to act morally but to obey other compelling motives. This thesis is tested against various objections, notably those which doubt the intelligibility or application of such non-moral 'respect', or would assimilate it to moral approval; and it is distinguished from various positions with which it might be confused, such as the 'admirable immorality' of Slote, or the Nietzschean critique of morality.
\end{abstract}




\section{RESPECT FOR JUST REVENGE}

The thesis of this paper is that, under certain conditions, an act of private revenge may properly be the object of a special kind of positive judgement, even though it is at the same time rightly morally condemned. The name I propose for this positive judgement is 'non-moral respect'. I will suggest in passing that respect of this kind can be extended to various other kinds of acts which are morally wrong, but the main focus of the paper will be upon revenge.

By 'private revenge', I mean a deliberate injurious act or course of action against another person, motivated by resentment of an injurious act or acts performed by that other person against the revenger, or against some other person or persons whose injury the revenger resents. Both motive (vengeful resentment) and injurious act must be present to constitute revenge. Within the motive, we could distinguish further between the passive resentment that is a response to the injury received, and the active vengeful feeling that empowers the decision to strike back, but I will not pursue this distinction, since for revenge both components must be present: where only passive resentment is felt, we have not revenge but forbearance, or impotent embitterment.

The adjective 'private' serves to exclude cases in which the revenger acts with institutional authority. We must set aside the important, but for present purposes 
irrelevant, debates over whether institutionalised punishment is itself a form of revenge, is motivated by vengefulness, is necessary to prevent affronted citizens from acting vengefully, and so on. ${ }^{1}$ Some recent writers have sought to rehabilitate revenge as a justification, or legitimate function, of legal punishment, but I do not propose to build on these arguments to vindicate private revenge in moral terms. ${ }^{2}$

I will assume, on the contrary, that we are all agreed that such revenge is indefensible within morality (and I will briefly say why); my purpose will be to show that it is capable, under certain conditions, of a well-founded respect which is based on its standing outside morality, as a choice by the revenger not to act morally but to follow other motives. The revenger in these cases acts as she does because she feels that her whole life would be spoiled or falsified if she did not pursue revenge, even though she knows she ought not to pursue it. I will suggest an analogy between these cases and certain acts expressive of love, such as protecting from detection and arrest one's child who is a violent criminal even though he is likely to continue to offend against others: one knows that one ought to prevent this, but decides that one's life would be spoiled if one injured the interests of one's child so deeply.

Acts of revenge which may elicit respect need to be distinguished from other, superficially similar, acts which can justify no respect, such as sadistic acts against others for which retribution for an injury is a mere pretext; or cases where the original offence motivating revenge is too trivial for a reasonable person to resent, or the degree of retaliation is excessive, or the offender is afflicted by means of an injury to an innocent third party, or the vengeful act is reckless and unfocused (e.g. rushing out into 
the street in a rage and shooting wildly). Eliminating these cases of sadistic, superfluous, disproportionate, misdirected, and whimsical revenge leaves us with acts of just, proportionate and accurately-directed revenge. Though I will assume that we all agree that these acts too are morally wrong, I will argue that they may be eligible for non-moral respect.

It will already be clear that some conceptual stage-setting is needed before the argument can proceed further. The idea of respect for an action, and in particular for an action morally disapproved of (non-moral respect), needs explanation; and an account of morality needs to be given which shows why respect for an act of revenge must necessarily be distinct from moral approval, and indeed needs to be consistent with moral disapproval.

The latter task is the more difficult, since (as we shall see later) a likely type of objection to my argument is that the scope of moral approval, properly understood, embraces all the judgments I can plausibly ascribe to non-moral 'respect'. I will try to answer these objections as they arise, and for the moment will confine myself to indicating the kinds of widely-held moral principles which I take to condemn acts of revenge. I will assume that the condemnation has its justification either in altruism or in considerations of social safety. In the first place, an act of revenge causes harm or affliction to another, and so is denounced by the moral principle best summarised by 
Schopenhauer: "Injure no one; on the contrary, help everyone as much as you can". ${ }^{3}$ In the second place, a range of moral beliefs which can be formalised within quite diverse philosophical traditions -utilitarian, Kantian, contractarian- concur in disapproving private acts of revenge on the grounds that, once normalised through imitation and counter-retaliation, they destroy social order, including lawful means of redress, and return us to 'the war of each against each'. I will assume that both the agent who commits an act of revenge, and the observer who comments upon it, subscribe to at least one of these moral arguments, and so have no doubt that revenge is morally unjustified.

In sketching these moral arguments which condemn private revenge, I have deliberately avoided invoking any connection between justice and morality. Some readers may already be disquieted by the suggestion, at the end of section $\mathbf{I}$, that an act which is able to be characterised as 'just' may nevertheless be morally wrong. It would be possible, indeed, to argue that revenge is not morally wrong if it is just; or to argue that, because it is morally wrong, it cannot be just. To resolve these questions would require a fuller examination of the relation between morality and (retaliatory) justice than is possible in this paper. For the moment, I will simply suggest that the idea of a just but morally wrong action is not entirely counter-intuitive. If I strike you without good reason, and in response you strike me back, we may both be acting wrongly and both be breaking the law, but you have a ground for complaint over my action that I do not have over yours. You can appeal to a complaint-grounding reciprocal principle such as mutual forbearance or non-violence in interpersonal relations; I cannot consistently appeal to the same reciprocal principle, since I have myself have rendered such reciprocity of non-violence between us inoperative. Indeed any assumption of reciprocity should now 
lead me to expect to be struck in return. We do not need to invoke the lex talionis to see that, in at least a minimal sense of the term, your act is just whereas mine was unjust.

Respect for an action I define as a feeling of sympathy grounded in the belief, on the part of an observer, that she might herself intentionally and after sober deliberation have performed or wished to perform the action in the given circumstances as she understands them. (The addition of 'wished to perform' takes account of cases in which one respects an action which one lacks the skill or courage or energy to perform.) Respect for an action which the observer morally disapproves of requires an additional thought: "I might have performed or wished to perform this action without ceasing to be the morally serious person I take myself to be".

It may help to understand this characterisation of respect for an action if we look at the parallel case of respect for another's belief which one may or may not agree with. ${ }^{4}$ Here there are three rational alternatives among the four which are logically possible.

A1 I agree with and respect your belief that X.

A2 I agree with and do not respect your belief that X.

A3 I disagree with, but respect, your belief that X.

A4 I disagree with, and do not respect, your belief that X.

In A1 the first proposition entails the second, while A2 is self-contradictory: to agree with a belief that $\mathrm{X}$ is to be conscious of being a person who believes that $\mathrm{X}$, but 
(adapting the definition of respect for action just given) not to respect the belief that $\mathrm{X}$ is not to believe that one could oneself agree that $\mathrm{X}$.

The difference between A3 and A4 is that in the case of A3, but not A4, I believe that I might have held belief $\mathrm{X}$ without ceasing to be the reasonable person I take myself to be. For example: I disagree with, but respect, the belief that George W. Bush was wrong to authorise an invasion of Iraq. I disagree with, and do not respect, the belief that George W. Bush is a literal incarnation of the Great Satan. The latter view is not eligible for consideration by a reasonable person, such as I take myself to be, whereas the former is a view which I might well have arrived at by the exercise of reason, though I have in fact concluded that it is false.

If we turn now to the analysis of respect for actions, there is a considerable degree of symmetry, but also some crucial points of asymmetry, with the analysis of respect for beliefs.

B1 I morally approve of your action Y, and I respect it.

B2 I morally approve of your action Y, but I do not respect it.

B3 I morally disapprove of your action Y, but I respect it.

B4 I morally disapprove of your action Y, and I do not respect it.

In $\mathrm{B} 1$, unlike A1, the first proposition entails the second only if we introduce a condition: that the observer is conscious of being a person capable of acting according to the requirements of morality. (A thoroughgoing immoralist might recognise the 
action as the kind of thing approved of within morality, yet not respect it because she could not imagine herself intentionally performing it or wishing to do so.) We need the same condition to make B2, as well as A2, self-contradictory. The reason for the asymmetry here is that action, unlike belief, requires a voluntary commitment which can be refused: to agree with a belief is ipso facto to hold the belief, but to approve the performance of an action is not ipso facto to perform it, to be able to do so, or even to wish to do so.

B3 and B4 differ in the same way as A3 and A4: in the case of B4, unlike B3, I believe that I could not perform $\mathrm{Y}$ without ceasing to be the morally serious person I take myself to be (assuming I do take myself to be such a person). (Incidentally, it should be admitted that there exist people for whom there are no examples of A3 or B3, who are unable to feel respect for beliefs which they do not agree with or actions which they do not morally approve.)

However, there is a crucial difference between A3 and B3. In the case of A3, it is impossible for the other person to assent to my judgement, since it is logically impossible to disagree with one's own belief. In the case of B3, the other person may assent: that is, she may agree that her action should be morally disapproved of, yet understand that I might respect it in the sense that I believe that intentionally and after sober deliberation I might have performed or wished to perform the action in the given circumstances. The importance of this difference lies in the fact that an agent performing an act of revenge may take up the position represented by B3, not least to preserve her own self-respect. 
I maintain, then, that B3 judgements exist; and I believe we will understand our own collective attitudes to revenge better if we acknowledge that they do, and reflect upon the significance of B3 judgements about revenge.

Two related objections are likely to suggest themselves at once. We might deny the coherence of B3, that is, deny that there exist actions which justify both moral disapproval and non-moral respect. I have already said that there exist people for whom there are no instances of B3: perhaps they are right. Or we might reject as a confusion the concept of non-moral 'respect' itself. These are mutually supporting objections, since if there is no such thing as non-moral respect, there cannot be actions to which it is applicable; and if there are no intentional actions contrary to morality which merit some kind of non-moral benign response from observers, then there is no need for what I have labelled 'non-moral respect'. Both the thesis and the two objections seem to require to be tested across the field of imaginable examples, and I will try to clarify and vindicate the thesis by bringing forward examples which will advance the debate.

The first objection can be developed as follows. There is no realm outside morality in which respect for actions can nevertheless be accorded. Across the range of actions which may be supposed to be candidates for B3, those that are really respect-worthy are the morally justified ones (or actions are respect-worthy to the extent that they are 
morally justified); conversely, those that are not morally justified are not respectworthy. Separating actions into these two categories by the application of moral judgement removes the need for any 'special' kind of non-moral respect.

I begin to reply to this objection with my first example.

Alberto's daughter is shot dead by a Ruritanian diplomat. Because of diplomatic immunity, and the absence of reciprocal trial or extradition agreements between Italy and Ruritania, the killer is able to return home without facing charges. So poor is the historic relationship between the two countries that Alberto knows that the likelihood of legal redress in his lifetime is negligible. He believes in the Christian morality of forgiveness, and the secular consequentalist arguments for the futility of revenge -perhaps he even believes that his immortal soul is forfeit if he kills someone- but he finds that he cannot live out the rest of his life without an unbearable and perpetual sense that the most important thing in it, the only thing that now gives it meaning, his urge to revenge his daughter, is unrealised. He tracks the killer to Ruritania and shoots him dead.

Consider, first, whether you judge Alberto's action to be morally right or wrong. Then, consider whether you feel respect for his action. Does the course of reflection on the second point precisely map the course of reflection on the first?

I believe most people will have difficulty in confirming that it does, if only because they are more likely to hesitate over the second question than the first. The action is a 
dreadful one, and a crime in any civilised jurisdiction, so moral disapproval seems clearly in order, yet that disapproval is likely to be accompanied (as it would not be in the case of an unprovoked murder) by a certain misgiving as to unequivocally negative judgement, a misgiving which I will shortly try to explain and justify.

It is tempting to explain this misgiving, and at the same time preserve the dominion of morality over the example, by saying that one morally disapproves of the action, while feeling moral approval for a significant aspect of Alberto's motives. His motives are closely associated with his love for his daughter, and since loving one's close relatives is viewed favourably by most moral systems, we are not, according to this view, really stepping outside morality when we respect (and 'respect' here means 'morally approve of ') -not his action, but part of his motivation.

This explanation is inadequate, however. From the consensus that the emotion of love itself is of high value for the moral life, it does not follow that we either do, or should, view all motivation derived from love as to that extent morally commendable. ${ }^{5}$ There is something fishy about the idea that a morally commendable motive can have caused, or at least increased the probability of, a wrongful act. A motive which is capable, in combination with other motives, of making a wrongful action more likely must at any rate have its claims to be morally commendable called into question. A more plausible analysis is that, intuitively, we (1) morally approve the loving emotion, (2) morally disapprove the ultimate violent action, and (3) take a more complex view of the motives, intentions and decision that connect the one to the other. Acknowledging this 
complexity opens the door to the possibility that non-moral respect may be part of our complex response to Alberto's action and its causes.

Moreover, the grounds of our respect are not in fact likely to be restricted to the motive. I have noted already that Alberto's act is (in least in a minimal sense) just, and, irrespective of motive, this justness may be a factor in disposing us towards respect for the act itself, even if we agree with Alberto that it is morally wrong. The 'minimal justness' of his action is prima facie evidence of a degree of moral seriousness.

We cannot respect Alberto's action if we do not construe it as that of a reflective person to whom moral considerations are important. There are two reasons for this. Firstly, respect for an action requires that it proceed from a considered decision, not just the impulsion of a motive. Emotionally-driven incontinence could not be respected, even in such a case as Alberto's, though it could be pitied. In the second place, where an action is the outcome of a considered decision among alternative actions, it cannot qualify for respect if the morally-indicated alternative has not even been seriously considered, since the decision-making process has been grossly defective and the act retains to some extent the character of incontinence. But the fact that we require moral awareness and reflection by Alberto as a necessary condition if we are to respect his action does not mean that our respect is to be identified with moral commendation of his motive. Moreover, in order to feel respect, we must be convinced of the justifiable centrality and seriousness of the motive in the agent's life. We might perhaps respect a man's travelling to Ruritania to revenge a deliberately inflicted, permanently crippling injury to himself, but not his travelling to retaliate a transient scratch in a minor scuffle. 
An elaboration of the example will, I believe, bring out particularly clearly the divergence of respect from moral approval. Imagine an alternative version in which Alberto does not premeditate revenge but, happening to visit Ruritania and encounter the diplomat, kills him in a sudden fit of passion, without ever having reflected upon the moral arguments against doing so. The killing in this alternative version would generally be seen as less morally heinous than in the original version, because more excusable by the swamping of deliberation by emotion, yet the grounds for respect would be reduced, since there would be less evidence of the 'centrality and seriousness' of the issue in Alberto's life, or of his having soberly reflected upon it. Another way of characterising this distinction is to say that in this alternative case we would be more inclined to commiserate Alberto, than to respect him, for his action.

The crucial point is this: given the understandable centrality of the motive in his life, the more consciously Alberto has set aside the demands of morality after reflecting upon them, the more likely we are to respect (even though morally deploring) his action. Thus respect acknowledges the importance of morality, since it requires that a condition for respecting certain actions is that moral considerations should have been seriously considered before they are performed. But the respect endures up to, and beyond, the setting aside of the claims of morality. We respect and disapprove at once.

To capture the necessity of moral reflection as a condition for respect, I will not call actions like Alberto's 'immoral', since 'immoral' may be taken to imply that moral considerations have not even been seriously reflected upon. Instead I will call them 
'non-moral' when focusing on the fact that they have not been chosen for moral reasons, or 'anti-moral' when focusing on the fact that they contradict the course of action which morality would require.

To strengthen my general claim for the independence of a certain kind of respect from moral approval, here are two more examples, not involving revenge.

Bella, who lives for the happiness of her only son, discovers that he is a serial killer. She knows clearly that she ought to betray him to the police, and is tormented by the thought of the suffering of his likely future victims, which her inaction will have made possible. She tries to dissuade him from further crimes, though aware of the ineffectiveness of her pleading. But she cannot bring herself to betray him to life imprisonment, or the death penalty: her whole remaining existence would be spoiled by the knowledge of his inevitable suffering, and his equally inevitable hatred of her as his betrayer. She chooses to obey this motive rather than to do as she knows she ought.

Charles has been estranged from Louise for ten years, but is still deeply in love with her. Nothing is more important in his life than this love. Meeting her again, he discovers that she is now happily married to Stuart, has children to whom she is devoted, etc. He knows that there is no prospect whatever that she will leave Stuart and return to him. He learns that Louise, though she no longer loves Charles, has been troubled by guilt and anxiety about his wounded feelings, and would be significantly happier if he assured her that he was contented and had 
not been unduly grieved by unrequited love. Her misgivings on this point have had some negative impact on her marital and family life. Charles is a sufficiently good actor to reassure her with conviction if he so chooses, or to behave in a way from which his contentment can confidently be inferred. He knows that Louise and to a lesser extent her family will feel bad if he reaffirms his love for Louise: he accepts the argument that it would be 'selfish' for him to do so. Nevertheless, when the occasion arises for him to make a statement, he decides to set these moral considerations aside, and says truthfully that he still loves her and has never ceased to suffer from his love. He says this because the love is the central fact about his existence, and to deny it -or even remain silent about it when an occasion to discuss the matter naturally presents itself- would be to deny what above all in life he wishes to affirm.

In both these cases, it is possible to 'moralise' the agent's motives: one can say, for example, that Bella is motivated by the special obligation of a parent, and Charles by a punctilious truthfulness. But this would miss the point. Neither Bella nor Charles is unaware of the many moral considerations that bear upon their predicament: like Alberto, they are essentially good people, alert to such considerations. Both decide surely rightly- that the weight of moral argument lies with the decision that they nevertheless do not take. The decision to act, then, is not capable of being moralised. The lesser moral argument in its favour is irrelevant: Bella does not shield her son because she believes in the special obligations of parents, and Charles does not assert his love because he recognises the utility or deontic necessity of truth-telling. They choose their actions for non-moral reasons which (if my intuitions are trustworthy) we 
can respect on the same conditions as for Alberto: the legitimate seriousness and centrality of the motive in the person's life, and the sober recognition, even though they are set aside, of the claims of morality.

If we now look back at the revenge example, we are reminded that a special factor which characterises it, and is absent from the cases of Bella and Charles, is the justness of Alberto's act. Though anti-moral but respect-worthy actions are to be found in a variety of areas of human conduct, acts of revenge require what can only be called a political context. The very concept of revenge implies the existence of some system or culture of peaceful reciprocity among human beings, which the original offender has transgressed. (This could be very simple, such as the culture of mutual forbearance between two people cast away on a desert island.) Revenge requires, indeed its logic appeals to, conscious reciprocity. If Dave punches me and I punch him back because his punch has put me in a fighting mood, or because I am hurt and lash out instinctively, or simply to protect myself against further punches, these are not cases of revenge; only if I think

You, Dave, punched me, so I will punch you

-in other words, if there is in my thought an invocation of reciprocity, however informal, as signalled here by the logical connective 'so'- am I exacting revenge. This 'political' condition of revenge is another question too complex to pursue here, but it suggests the following thought: that reciprocity in an action may be a contributory condition for earning respect, yet not for earning moral approval. That I am 
reciprocating the wrongful act of another does not prevent my action from being morally wrong, but it provides some evidence of the deliberation which is a prerequisite for earning respect, and it may attract sympathy to the extent that in it I am conforming to a template of human action which I have not initiated (in contrast to the gratuitous act of the original assailant.). In short, my act is (minimally) just even though it is morally wrong.

If the reader is tempted to maintain -perhaps invoking the diversity of moral codes- that the possibility of respect for the kinds of actions we have been discussing must be capable of being brought within the category of some kind of moral approval, it is worth pointing out how strange it is that this need not seem to be the case to the agent himself. For it is clearly possible both (i) to act against whatever moral principles one holds, and (ii) to act in a way which would be compatible with a certain set of moral principles, without actually holding to those principles. To the argument that Alberto, for example, must be practising 'a vendetta morality', or 'a revenge morality', the reply is, firstly, that even if he supported such a morality, it need not be his reason for acting, and secondly that it would not be necessary for him to believe in any such morality in order to do what he does. In short, no moral code, once an agent is aware of it, can be the sufficient explanation of his deliberate actions. To bring all actions within the scope of some moral code, we would have to take refuge in the claim that whatever a person actually does must represent 'his real morality', and that the moral principles Alberto, Bella and Charles suppose themselves to have considered and set aside, after painful and profound struggles of conscience, are not 'really their moral principles' at all. But this is to empty the concept of morality, or moral codes or principles, of any content. 


\section{IV}

The second type of objection to the thesis that B3 judgements exist seeks to invalidate the very notion of 'non-moral respect'. It is connected to the first objection in that, in one version, it denies the possibility of respect for actions independently of moral approval of actions. 'Respect', on this first version of the second objection, is simply an aspect of moral approval, or, more loosely, a vague feeling of commendation which can only be given determinate application if its morally approving nature is brought into focus. An alternative version of the second objection suggests that, properly investigated, the supposed phenomenon of respect for actions recognisable in our intuitions will prove to have no determinate content, and to be merely a mixed bag of different attitudes sympathy or compassion for the agent, partial agreement with her values, recognition of mitigation or excuse, etc.

How, then can 'respect' as I have been using the term be given more determinate meaning? Among our fellow citizens we can distinguish three broad groups, on the basis of the overall pattern of conduct they display: first, those whose actions suggest that they live as strictly as they can according to the demands of morality (as they or we conceive those demands); second, those for whom morality provides a part of their motivation, but who will sometimes prioritise non-moral motives for action over those derived from morality, and third, those who actions suggest that they live mainly or 
exclusively according to non-moral imperatives. In short, some lead the moral life as they understand it, some orient at least part of their conduct towards it, and some are indifferent to it. (As I have already implied, an underlying assumption of the present discussion is that the moral life has some determinate content, difficult and contentious though we may find the task of describing it, and is not merely a formal name for whatever pattern of priorities governs the conduct of any given person.) Of course this tripartite division is simplified, the first and third categories fitting exactly only the occasional Mother Theresa or Heinrich Himmler, but everyone will be able to identify among their acquaintances people for whom moral considerations appear to weigh unusually heavily or unusually lightly.

Most people will, I suspect, place themselves in the second, intermediate category, aware that their actions and motivations do not entirely track morality, and perhaps wishing -though not usually very intensely- that they could track it more consistently. An explanation of respect might then take its cue from a distinction Aristotle draws in the Poetics when he identifies the appropriate kind of protagonist for tragedy. ${ }^{6}$ We admire those who, unlike us, belong to the first group and despise those who, unlike us, belong to the third. But a special kind of sympathy attaches to those who are alongside us in the middle, a sympathy that may rise to respect if they seem to be closer to the moral end of the spectrum than we are, or to perform an action that places them there.

So far, this kind of respect equates to, or at least is dependent on, moral approval of an action or a pattern of conduct. How, then, can there be respect for non-moral, or antimoral actions, such as those of Alberto, Bella and Charles? The answer begins with the 
observation that the excursions from the moral life performed by those of us in the middle group can themselves be categorised in various ways by their motives. Four such categories, with examples, are:

1 The negligent. I ought to pay a visit to a relative who would be quite glad to see me, but I decide to stay at home and watch television instead.

2 The frivolous. I refrain from offering a needed lift home to a colleague because he disagreed with me in a committee debate.

3 The sensuous. I eat the large chocolate bar my parents left for my children on their recent visit.

4 The serious. The decisions of Alberto, Bella and Charles.

Intuitively, we want to say more, evaluatively, than that all four of these are infringements of the demands of morality. If we try to rank them using a moral criterion, the natural way to do so is in terms of the degree of harm they do, expressing this either as disutility or as outrage to moral principles of varying degrees of importance. On this moral criterion, example 4 would rightly be judged most negatively, since the revenger or the child-protector does incomparably more harm than is done in the other cases, and even the love-affirmer does considerably more. There is, however, another kind of evaluation, on which the revenger, child-protector and loveaffirmer come out ahead of the frivolous, negligent and sensuous person; and the best 
description for the judgement emerging from this evaluation is respect for non-moral or anti-moral action. It is related to the wider 'Aristotelian' moral form of respect by the condition that the respected agent (unlike the negligent, frivolous or sensuous antimoralist) will have reflected seriously on the demands of morality before setting them aside. Anyone who meets this condition will be recognised by us as belonging, like us, in the intermediate moral group -'those for whom morality provides a part of their motivation'- and the serious nature of their grounds for rejecting morality may even cause us to place them among the better members of the group. Another way of putting this is that we respect their actions because we think "I can imagine myself, in my most serious moments, perhaps choosing as they have chosen".

A final objection now presents itself. A critic might argue as follows.

"I agree that I may be able to 'imagine myself, in my most serious moments, choosing to perform', certain actions of which I morally disapprove. I could not, therefore, deny a kind of fellow-feeling with those other agents who, having met the condition of seriously reflecting on the demands of morality before setting them aside, actually perform such actions. But some of these actions might be so bad that I would unequivocally deplore them, in spite of my recognition that I myself, even in my most serious moments, might have performed them. Now 'a kind of fellow-feeling' is compatible with this unequivocal deploring: it just means that I realize that I can act as badly as the next person. 'Respect', on the other hand, suggests something which is, in however qualified a way, a positive feeling. The explanation of my respect for Alberto as being founded purely on the thought that "I can imagine myself, in my most serious 
moments, perhaps choosing as he has chosen" cannot be correct, since that thought is compatible with unequivocal deploring -that is, the entire absence of any positive feeling- and respect is a positive feeling. My respect must, therefore, be founded in addition on something else -most plausibly, on some moral consideration, such as the thought that Alberto's killing of the diplomat would have been even more deplorable if it had not been provoked.”

The key to this objection is the claim that 'some actions might be so bad that I would unequivocally deplore them, in spite of my recognition that I myself, even in my most serious moments, might have performed them'. What kinds of actions can be supposed to motivate this response? It is not enough that they should motivate unequivocal moral disapproval, since the point in dispute is precisely whether there is such a thing as a non-moral positive judgement that can co-exist with unequivocal moral disapproval. There must be some additional heinousness or disgracefulness to the act, going beyond what is sufficient to ensure moral disapproval, which prompts the observer, not merely to disapprove morally, but to foreclose any possibility even of a non-moral positive feeling which could credibly be described as 'respect'-while yet accepting that she can 'imagine herself, in her most serious moments, choosing to perform it'. Are there any such acts?

The examples which may seem to substantiate the objection will, I believe, lose their force provided we unpack a little the criterion of 'serious reflection on the demands of morality'. It is true, for example, that my judgement of another's action may have a wholly negative character, even if I believe that I myself might have performed the 
action, if it is a moral lapse of a kind I know I am prone to. Perhaps, for instance, I am prone to strike people when arguments become heated: my fellow-feeling would not cause me to respect another person who did the same. But we recall that it is a condition for respect that the agent should have reflected seriously on the demands of morality before setting them aside. To speak of a 'lapse' is precisely to assume the absence of any such reflection: serious reflection on the demands of morality precludes the kind of incontinence of decision-making which can be characterized as a 'lapse'.

Equally, the requirement that the reflection be 'serious' may be taken to preclude the kind of 'reflection on the demands of morality' which makes those demands subservient to some extra-moral end, as in the thought process of a sadist who dwells on his moral obligations in order to enjoy transgressing them. The serious setting aside of moral obligations cannot be a pleasurable process.

In contrast, the person whose excursion from the moral life can be categorised as 'serious', and so eligible for respect, must keep the demands of morality in continuous view, so to speak, and in painful contradistinction to the act he or she decides to perform. That persevering clarity and that painfulness of reflection constitute the seriousness which provides the foundation for our respect for Albert's decision. 
Before concluding the paper, I will distinguish my argument for the possibility of nonmoral but respect-worthy actions from various other views with which it might be confused.

First, it is not to be construed as a denial of the thesis that moral considerations should (or for a wholly rational person, actually do) override all others. The presupposition of the thesis is that a rational person can engage in a process of practical reasoning in which moral and non-moral considerations are weighed against one another. ${ }^{7} \mathrm{My}$ argument does not require this presupposition, and I think it is more plausible to suppose that no decisive adjudication before the court of reason between moral and nonmoral considerations is possible: that, roughly speaking, moral considerations are overriding from the point of view of the moral life, if that is the one we wish to lead, while various non-moral considerations are overriding from various other points of view. But even if this presupposition of the overridingness thesis were true, one can imagine Alberto, Bella or Charles doing what they actually do, even after deciding at the court of reason that they ought to do otherwise. If it is possible to renounce the demands of morality in a particular case, it is possible to renounce the status of a wholly rational person, if one believes that such a person could not renounce morality.

Second, my view is not, of course, to be confused with the claim that some people act non-morally out of some special psychological compulsion. The interest of cases like those of Alberto, Bella and Charles lies in the fact that they could act otherwise than they do (setting aside determinist arguments that are equally applicable to all human action), and would survive as sane human beings if they did so, but would then feel -or 
at least would now predict of themselves that they will feel- that their life has been spoiled.

Third, the non-moral defence must not be confused with a Nietzschean rejection of morality itself, or even with the more cautious questioning of the scope of morality's demands on us that we find in the work of more recent philosophers such as Bernard Williams. ${ }^{8}$ On the contrary, I have emphasised that a condition of our respect for these agents is that they should take morality very seriously: they may even sincerely believe in its 'overridingness'.

Fourthly, as I implied above, the kinds of acts defended by the non-moral defence cannot be explained away as acts morally justified in rule-utilitarian terms though happening not to be 'optimific' in the particular case. A utilitarian rule regarding parents' love for their children (or the fostering of such love by our laws and culture) cannot be supposed to be formulated so loosely as to fail to exclude killing or omitting to save the lives of others.

Nor, fifthly and conversely, are they examples of bad acts carried out for countervailing, and overriding, utilitarian reasons, such as the torturing of a terrorist to extract information which will save the lives of many others. They are wrongful acts carried out in defiance of the most compelling moral arguments recognised by the agent, not to fulfil what the agent believes to be overriding moral arguments. (The difference of tone here between 'wrongful' and 'bad' reflects the fact that torturing someone is an act which decent people cannot respect, because they cannot 'imagine themselves, in their most 
serious moments' choosing to perform it -and certainly not if it is done in defiance of a person's best moral judgement.)

Sixthly, these are not the type of cases, identified by Michael Slote, in which a virtue outruns its connection to morality and yet remains, even while doing so, an 'admirable' virtue. Slote gives the example of Winston Churchill's single-mindedness in fighting Nazism, which we continue to admire (he says) even when it leads Churchill to the immoral act of approving the deliberate bombing of large numbers of German civilians. ${ }^{9}$

Superficially, there is a certain resemblance between the idea of admiring a virtue, without necessarily morally commending a particular course of conduct which exemplifies it, and the idea of respecting an action which is contrary to the demands of morality but is motivated by some concern central to the agent's life. The resemblance lies in the fact that in both cases morality yields ground to something else, which is nevertheless viewed positively in some way. Even in the relation to morality, however, there is a crucial difference. In Slote's analysis, it is effectively stipulated from the beginning that we are to think of virtues as only partially or loosely correlated with actcentred moral commendation: indeed, since his purpose is to supplant act-centred morality with an ethics of virtue, Slote needs to vindicate the looseness of this relation (since if virtues could be paraphrased as sets of act-centred injunctions, the replacement would be unnecessary). By re-tightening this loose connection, as it were, we can remove the difficulties raised by Slote's cases. In the Churchill case, it is true that we have independent evidence of Churchill's single-mindedness in fighting Nazism, and if 
we admire this as a virtue we are involved in a certain dilemma of assessment when this very virtue causes an immoral act, especially if we believe, as Slote suggests, that Churchill could not have done otherwise given his possession of this particular virtue. But we can resolve this dilemma, without doing harm to common-sense intuitions, by abandoning the assumption that single-mindedness in fighting Nazism is entirely a virtue, since we see that it can sometimes lead to immoral acts, and we think immoral acts are inconsistent with virtue; or, more generally, by recognizing that the moral significance we attach to anyone's personal qualities (a significance which may sometimes lead us to say they possess a virtue) is merely a summary of our assessment of the moral worth of the actions they motivate, and so undergoes perpetual revision as new actions are added. We are not obliged (except perhaps by some versions of virtue ethics) to say of any personal quality, "once a virtue, always a virtue".

In contrast, in my explanation of respect for non-moral actions, morality is assigned a fixed position, in that its demands have been consciously identified and then set aside by the agent after serious reflection. In my examples, there is no dilemma to resolve: rather, there is a complete stand-off between the admitted demands of morality and what the agent decides to do.

Moreover, our non-moral respect for the actions of Alberto, Bella and Charles is not dependent on our having any independent evidence of their actions instantiating some admired virtue they possess. We could respect Alberto's action, for example, even if he had previously shown mainly the virtue of forbearance, which his action repudiates, and not particularly the kinds of virtues under which his revenging action might possibly be 
subsumed, such as resolution or a sense of justice. Admittedly, we could find in Alberto's or Bella's actions the 'virtue of parental love' outrunning morality, while Charles's could exemplify the 'virtue of frank speaking', or the 'virtue of enduring erotic love'. But even if we admit these to the canon of virtues (and they are surely more generally understood as natural inclinations to which most people attach a lot of importance), it is implausible that we should ground our respect for the actions upon these virtues. In Slote's Churchill case, we look to Churchill's virtue as an excuse for an action we condemn (or if we do not condemn it, it is because we believe it to be morally justified for some reason): we think "I can imagine that a person with this special virtue might commit such an act". In the cases of Alberto, Bella and Charles, we do not look for an excuse for the act, because it is the act itself we respect: we think, "I, an ordinary person without a special virtue, might commit this act".

A closer analogy to our respect for certain actions counter to morality is provided by Slote's development of the 'Gauguin' example, introduced by Bernard Williams to support the notion of 'moral luck' in 1976 and widely discussed thereafter. ${ }^{10}$ The painter Gauguin decides to abandon his family and to settle in Tahiti, in the belief that this will liberate his artistic potential. Let us follow Slote in judging that this is an anti-moral act, and that it is motivated by a non-moral value central to Gauguin's life, his 'passion for art'; let us add, to bring the example closer to those of Alberto, Bella and Charles, that Gauguin considers the claims of morality very carefully before deciding to ignore them. If we set aside, as Slote does, various attempts at moral justification for Gauguin's desertion of his family, then we may be prepared to say that we respect Gauguin's nonmoral passion, even though we condemn the anti-moral act to which it leads him. In 
contrast to the Churchill case, we do not need to view the passion for art as a virtue; the point of our respect is that it matters intensely in Gauguin's life -more intensely, it turns out, than morality does- and we can understand that there might be something in a person's life that matters even more than morality. If we have our own share of the passion for art, we may particularly readily understand why a creative artist would attach an enormous value to it. However, I am less convinced that we are likely to respect the anti-moral act in Gauguin's case than in the cases of Alberto, Bella and Charles. I can think of two explanations for this intuition, and the explanations have a common underlying feature. Firstly, it is harder in Gauguin's case to give credence to a belief that his life would be spoiled if he did not leave his family and go to the South Seas: because of the unpredictable course of an artist's creative development, and the possibility that family life and creative fulfilment might after all be capable of being reconciled, the situation is less critical, less all-or-nothing than in the other cases. Secondly, Gauguin's decision, in contrast with those of Alberto, Bella and Charles, is to undertake a course of action likely to lead to pleasure, fulfilment and fame for himself, and these prospects are very different from that of allaying an intolerable pain. The common underlying point is that Gauguin's decision (as Williams sees clearly) is part of a long-term life project, and renunciations of morality are likely to seem to an observer less eligible for respect when they occur in the course of an agent's planning a long-term project than when they occur in the face of a crisis not of the agent's own choosing. One thing we respect people for is the work they put into reconciling their projects with morality, and they may forfeit our respect if they seem to be shunning this work; but it is a distinctive feature of the predicaments of Alberto, Bella and Charles that they are externally imposed and cannot be planned for. For similar reasons, we may respect, 
without morally commending or excusing, the decision which puts aside moral constraints in the service of a quite exceptional and overpowering erotic passion. (This is why the love-potion inadvertently drunk by Tristan and Isolde prior to their adultery is important. It does not create their mutual passion -at least not in Wagner's version of the story- but it provides an external symbol of its exceptional, and as it were involuntary, nature, and so helps the audience to view Tristan's consequent betrayal of his loyalty to King Marke, by which he is himself deeply grieved, with a certain sympathy.) On the other hand, a man's rejection of moral obligations in the pursuit of a sustained project of having sex with as many women as possible may be understood but hardly respected.

\section{VI}

I have tried to demonstrate the possibility of respect for certain kinds of actions which are contrary to the demands of morality. Among the actions we can feel this kind of respect for are acts of private revenge, under certain conditions which include their being just. If this idea is accepted, it may contribute something to various questions in moral and political philosophy. Among other possibilities, I believe it will help us towards an understanding of how actions may be just and yet morally wrong, and of the complex reciprocal character of political life. 
RESPECT FOR JUST REVENGE

\section{NOTES}

${ }^{1}$ It is a feature of the existing literature, however, that discussion of private revenge (or more commonly, of vengeful attitudes and emotions, as distinct from acts) almost always occurs in the context of theories of law, justice and punishment. There are widely divergent views on the relation of vengeance to lawful punishment (ranging from the firm separation proposed by Hobbes, Bentham and others, through the disquieted equivocation of Sidgwick, to the suspicions voiced by Durkheim and Nietzsche that the latter is a rationalisation of the former), and to disentangle the one 
theme from the other in the literature would require a separate paper. For some examples of this entanglement, see Aristotle, Nicomachean Ethics, tr. J.A.K.Thomson \& H.Tredennick (Harmondsworth: Penguin, 1976), IV, v (1126a), 161-2, and V, v (1132b-1133a), 182-4; Kant, The Metaphysical Elements of Justice, tr. J.Ladd (Indianapolis: Bobbs-Merrill, 1983), 100-102, and 'Vengeance', Lectures on Ethics, tr. L.Infield (London: Methuen, 1930), 214; Hobbes, The Elements of Law, ed. J.C.A.Gaskin (Harmondsworth: Penguin, 1994), ch. IX, 52, and Leviathan, ed. R.Tuck (Cambridge: Cambridge University Press, 1996), ch. XV, 106, ch. XXVIII, 215-6; Locke, Second Treatise of Government, ss. 8-9, ed. P.Laslett (New York; Cambridge University Press, 1963), 312-3; Bentham, Principles of Morals and Legislation (Oxford: Blackwell, 1967), X, 10 \&n, 218; X, 26, 230-231; X, 34, 236; XIII, 2 \&n, 281-282; T.H. Green, 'Principles of Political Obligation', L, Works of Thomas Hill Green, Vol. II, ed. R.L.Nettleship (London: Longmans, Green and Co., 1893), 486-511, esp. 487-9; Sidgwick, The Methods of Ethics, 7th Edition, 1907 (London: Macmillan, 1967), VII, 1, 321-324; Durkheim, The Division of Labour in Society, tr. W.D.Halls (London: Macmillan, 1984), 44-52;. D. Garland, Punishment and Modern Society (Oxford: Clarendon Press, 1990); Ted Honderich, Punishment (Harmondsworth: Penguin, 1971), 15, 42-3; and Nicola Lacey, State Punishment (London: Routledge, 1988), 26, 34-5, 57, 184.

2 Examples are D.B.Hershenov, 'Restitution and Revenge', The Journal of Philosophy 96:2 (1999), 79-94, and Charles F.B. Barton Getting Even: Revenge as a Form of Justice (Chicago and La Salle, Illinois: Open Court, (1999). 
${ }^{3}$ Schopenhauer, On the Basis of Morality, trans. E.F.J.Payne (Oxford: Berghahn Books, 1995), 69.

${ }^{4}$ Or, if knowing another's belief is thought to be mysterious, of respect for another's expressed opinion which one believes to have been sincerely expressed.

${ }^{5}$ There is, of course, a long literary tradition of exploring the crimes into which love can lead us. The theme can be traced in the Paolo and Francesca episode in Dante (Inferno, V), in Arthurian tales such as that of Lancelot and Guinevere, and in the novels of Graham Greene (The Power and the Glory, The Heart of the Matter). The emotional power of these narratives comes precisely from their presenting the reader with this tragic tension between incommensurable values: the well-grounded law that condemns an immoral act, and the human power and dignity of the love that causes individuals, not unaware or disapproving of the law, to commit that very act.

6 13: 1453a ; Aristotle, Poetics, trans. M.E.Hubbard, in Classical Literary Criticism (Oxford: World's Classics, 1989), 66-67.

${ }^{7}$ See, for example, Neil Cooper, The Diversity of Moral Thinking (Oxford: Clarendon Press, 1981), 105-07; cf. Philippa Foot, 'Are Moral Considerations Overriding?', Virtues and Vices (Oxford, Blackwell, 1981), 181-88, and John Kekes, 'On There Being Some Limits to Morality', in Ellen Frankel Paul, Fred D. Miller Jr. and Jeffrey Paul, The Good Life and the Human Good (Cambridge: Cambridge University Press, 1992), 63-80. 
${ }^{8}$ See, for example, 'Morality, the Peculiar Institution', in his Ethics and the Limits of Philosophy (London: Collins, 1985), 174-96.

${ }^{9}$ Michael Slote, 'Admirable Immorality', in Goods and Virtues (Oxford: Clarendon Press, 1983), 77-107. See especially section IV, 93-100. I am indebted to this essay of Slote's at several points in the present discussion.

${ }^{10}$ Bernard Williams, 'Moral luck', Proceedings of the Aristotelian Society, supp. Vol. 50; reprinted in revised form in Bernard Williams, Moral Luck (Cambridge: Cambridge University Press, 1981), 20-39. For Slote, see note ${ }^{9}$. 